九州大学学術情報リポジトリ

Kyushu University Institutional Repository

\title{
Diallel Analysis of Plant and Ear Heights in Tropical Maize (Zea mays L.)
}

Ji, Hee Chung

Dept. of Tropical Plant and Soil Science, University of Hawai

Cho, Jin-Woong

Collage of Agriculture and Life Science, Chungnam National University

Yamakawa, Takeo

Faculty of Agriculture, Kyushu University

https://doi.org/10.5109/9234

出版情報：九州大学大学院農学研究院紀要. 51 (2)，pp.233-238，2006-10-27. Faculty of Agriculture, Kyushu University

バージョン :

権利関係 : 


\title{
Diallel Analysis of Plant and Ear Heights in Tropical Maize (Zea mays L.)
}

\author{
Hee Chung $\mathrm{JI}^{1}$, Jin-Woong $\mathrm{CHO}^{2}$ and Takeo YAMAKAWA* \\ Laboratory of Plant Nutrition, Division of Soil Science and Plant Production, \\ Department of Plant Resources, Faculty of Agriculture, Kyushu University, \\ 6-10-1 Hakozaki, Fukuoka 812-8581, Japan. \\ (Received June 5, 2006 and accepted July 24, 2006)
}

\begin{abstract}
Plant breeders and geneticists often use diallel mating designs to obtain genetic information about a trait of interest from a fixed or randomly chosen set of parental lines. Diallel designs and analyses have been developed for parents that range from inbred lines to genetically broad-based varieties. The object of this study was to determine the combining ability for the plant and ear height by both Griffing Method and Gardner \& Eberhart Method, and compare the results obtained by two methods. Hybrids and parents averaged over hybrids differed significantly for plant and ear height. Relative ear position over plant height (REPH) was also calculated from plant and ear heights. By Griffing Method, general combining ability (GCA) was significant in plant height. Specific combining method (SCA) was highly significant in all three measurements. Average heterosis for the plant and ear heights were $33.3 \%$ and $61.9 \%$, respectively. However, REPH showed $21.6 \%$ heterosis effect. The traits with low heterosis showed higher ratios of GCA/ SCA, while these ratios were smaller in traits with high heterosis. REPH could be used as one of valuable selection criteria over plant and ear heights in the breeding program for low ear height. Above mentioned two statistical methods produced some different results.
\end{abstract}

\section{INTRODUCTION}

The height of the stalk is determined by the number and length of the internode in maize. In this way, plant height can vary from $0.3 \mathrm{~m}$ to $7.0 \mathrm{~m}$, depending on the variety and growing conditions. Usually, early maturing varieties are shorter, and late maturing ones are taller. In a tropical climate, where the growing season may be as long as 11 months, some late maturing varieties reach a plant height of $7 \mathrm{~m}$. As a result of inbreeding, plant and ear height decrease, and the population become more homogeneous until it reaches the "inbred minimum". Plant and ear height not only depend on the genetic background of the varieties, but are also influenced by many environmental effects and the cultivated method. Owing to increased plant density, plant and ear height may increase as the plants compete for light (Park et al., 1989; Mason et al., 1974). Taller plants attached with more leaves need a larger growing area and lower plant density compared with shorter one (Begna et al., 2000). Manson et al. (1974) reported that dry matter yield showed a significant positive correlation to plant height and to ear height. Plant height is principally determined by the variety and sowing date (Baktash and Mazaal, 1985), and is also very important characters not only for breeding of new varieties of maize, but for green and dry matter production, and even for grain yield and harvest. This trait is controlled by the expression of many genes and by the interactions between these genes.

${ }^{1}$ Dept. of Tropical Plant and Soil Science, University of Hawaii, Honolulu, HI 96822, USA.

${ }^{2}$ Department of Crop Science, Collage of Agriculture and Life Science, Chungnam National University, Daejeon, 305-764, South Korea

* Corresponding author (E-mail: yamakawa@agr.kyushu-u.ac.jp)
Ear height is one of the most important selection criteria in most maize breeding program. Especially, ear height is of importance when it comes to root and stalk lodging. High ear position is like to become more susceptible to root and stalk lodging. Thus, plant breeders prefer to select for lower ear position. Looking at a relative ear position over plant height (REPH) may supplement selection for low ear position by ear height only. Plant height has been considered less important for selection. However, it may not be true in some areas where tall plant has disadvantage in maize seed production due to wind effect. For instance, maize breeders have attempted to incorporate a semi-dwarf gene such as brachytic-2 (br $\left.{ }_{2}\right)$ dwarfing gene which shortens the internodes below the ear to reduce plant height.

In spite of this gene, they produced the same or almost the same yield as their normal counterparts. This is why using these dwarf lines in breeding facilitates selection for lower ear height without significant yield losses. Another type of dwarfism, supposedly caused by the simultaneous effect of many genes, shortens the internodes only above the ear, so that plant height decreases without changing the ear height or other parts of the plant (Legg and Fleming, 1973). Selection for cold tolerance also decreases the plant height and cause early flowering (Mock and Bakri, 1976). During selection, other characteristics may change, together with the improved trait. Selection for earliness, for example, decreases plant and ear height, according to many authors (Nyhus et al., 1989; Troyer and Larkins, 1985). In contrast, selection for higher yield increase plant and ear height (Thompson, 1983). There are some cases when plant height increase while ear height decrease (Yap and Tan, 1974).

Many breeders have studied selection for lower ear height. The most outstanding of them might be Harville (1977), who produced many early and late maturing, 
low-eared varieties by recurrent selection. Plant height is strongly associated with the flowering date, because internode formation stops at floral initiation, which means that earlier flowering maize is usually shorter (Troyer and Larkins, 1985). A modern variety produces high yields despite early flowering. There is also a correlation between earliness and ear height. The higher the ear is, the later the plant matures (Surányi and Mándy, 1955), but earliness and lower ear height have no absolute reciprocality. There are correlations between many other traits and plant height. The number of leaves (Allen et al., 1973) and the grain yield are significantly correlated with plant and ear height (Mckee et al., 1974). Obilana and Hallauer (1974) found a significant correlation between plant and ear height in unselected inbred. Plant height is usually considered to be a simple inherited trait, determined by only a few genes. Edward et al. (1987) identified QTLs for plant height in maize. Hui et al. (1997) found 30 QTLs for plant and ear height. According to Veldboom et al. (1994), QTLs for plant height are in close proximity to loci of qualitative traits affecting plant height. Lee and Veldboom (1993) found a marker on the long arm of chromosome 1 which is closely linked to a QTL for plant height.

According to Sheridan (1988), there are at least 27 loci influencing the quantitative expression of this trait. Beavis et al. (1991) identified 14 QTLs, most of them linked to the loci of qualitative traits. Either dominance (Guo et al., 1986) or additive effects (Russell, 1976) are considered more important in the expression of plant and ear height, though some authors assign the differences in plant and ear height to extrachromosomal effects (Baynes and Brawn, 1973). Plant and ear heights showed a great deal of heterosis. In order to elucidate heterosis in the quantitative analyses, those traits may play an important role.

Plant breeders and geneticists often use diallel mating designs to obtain genetic information about a interest trait from a fixed or randomly chosen set of parental lines. The diallel genetic design and its various modifications have been used by breeders to evaluate the potential of populations for intrapopulational improvement and the usefulness of parents in interpopulational breeding programs, and to select inbred lines in hybrid development programs. Although several strategies for diallel analysis have been proposed, few of them are commonly applied. Diallel analyses have been developed for parents that range from inbred lines to genetically broad-based varieties (Griffing, 1956; Gardner and Eberhart, 1966). Computer programs have been developed for Griffing's diallel analyses (Burow and Coors, 1994; Magari and Kang, 1994; Zhang et al., 2005). Diallel analyses of broad-based populations (Gerrish, 1983; Mungoma and Pollak, 1988; Crossa et al., 1990; Quendeba et al., 1996; Widstrom and Snock, 1998) have generally been conducted according to Gardner and Eberhart (1966) analysis. The Griffing (1956) method and Gardner and Eberhart (1966) method have been widely used in various crops
(Dorrance et al., 1998; Bourland et al., 1999; Soriano Viana, 2000; Nigussie and Zelleke, 2001; Pratta et al., 2003; Doerksen et al., 2003; Subhan et al., 2003; Bodzon, 2004; Hakizimana et al., 2004; Zhang et al., 2005). The main reasons that justify the widespread use of the Griffing (1956) method are its generality, since the parents can be pure lines, inbred lines, or populations of a self-pollinated, cross-pollinated or intermediate species, and the ease of analysis and interpretation; the latter also characterizes the method developed by Gardner and Eberhart (1966). The genetic interpretation of parameters in the Gardner \& Eberhart and the Griffing models and the relationship between them are have been discussed by Vencovsky (1970) and Cruz and Vencovsky (1989), thereby making the methods more accessible to breeder.

Diallel analysis of self- and cross-pollinating populations is used to study the genetic control of quantitative traits (Jinks and Hayman, 1953), to assess general and specific combining abilities (Griffing, 1956) and to perform heterosis analysis (Gardner and Eberhart, 1966) and to provide plant breeders the valuable and practical genetic information involved in materials they are dealing with. Griffing (Griffing, 1956) and Gardner \& Eberhart (Gardner and Eberhart, 1966) methods are currently used in data analysis. The object of this study was to determine the general and specific combining abilities (GCA and SCA) for the plant and ear height by using both Griffing Method and Gardner \& Eberhart Method and to compare the results obtained by two methods in a set of diallel crosses.

\section{MATERIALS AND METHODS}

\section{Plant material and growth conditions}

Five elite public inbreds of tropical Maize (Zea mays L.) that were widely utilized in University of Hawaii were used in this study. Two tropically adapted inbreds (Hi26 and Hi34) have been bred at University of Hawaii, and Pi17, Pi23 and Pi31 originating from Philippines and converted in Hawaii, and they all using for silage and grain. The resulting ten hybrids and five inbreds were planted on September, 2004 at Waimanalo Research Station, University of Hawaii on Oahu at $21^{\circ} \mathrm{N}$ latitude and $30 \mathrm{~m}$ elevations. The experimental design was a randomized complete block (RCB) design with three replications. Each plot was a single row (5m longth) with $0.20 \mathrm{~m}$ between hills. Two untreated seeds were planted and resulting plants were thinned to one per hill at around three weeks after planting.

\section{Evaluation method of traits and statistical analy- sis}

Data samples of five plants per plot were used for statistical analysis. Ear heights were measured on five plants in each plot from the soil surface to the base of the top ear. Heterosis effects (percentage) for plant and ear height were calculated from the mid-parental value of the two parents as $\left(\mathrm{F}_{1}-\mathrm{MP}\right) / \mathrm{MP} \times 100$, where $\mathrm{F}_{1}$ is cross and MP is average of two parents included in $\mathrm{F}_{1}$. 
The diallel crosses were analyzed following Griffing (1956) method 2 (including parents without reciprocals), model 1 (fixed) and model 2 (random):

$$
\mathrm{Y}_{\mathrm{ij}}=\mu+\mathrm{g}_{\mathrm{i}}+\mathrm{g}_{\mathrm{j}}+\mathrm{S}_{\mathrm{ij}}+\mathrm{e}_{\mathrm{ijk}}
$$

where $Y_{i j}$ is the mean phenotypic value, $\mu$ is the general mean, $g_{i}$ and $g_{j}$ are the general combining ability (GCA) effect, $\mathrm{S}_{\mathrm{ij}}$ is the specific combining ability (SCA) effect and $e_{i j k}$ (between ith and jth lines) is the error. Analysis III of Gardner \& Eberhart Method was also used with Ordinary Least Squares (OLS) estimation (Huber et al., 1992). The model for estimating the combining ability effects for each cross was

$$
C_{i j}=\mu_{\mathrm{c}}+g_{i}+g_{j}+s_{i j}
$$

where $\mu_{\mathrm{c}}$ was the mean of the population crosses, $g_{\mathrm{i}}$ (or $g_{\mathrm{j}}$ ) was the GCA effect, and $\mathrm{s}_{i j}$ was the SCA effect for the cross between the $i$ th and $j$ th parents such that $\mathrm{s}_{i j}=\mathrm{s}_{j i}$ (no reciprocal effect).

\section{RESULTS AND DISCUSSION}

Overall performance of the experiment followed a typical pattern at this time of season. With regard to plant height, ear height and relative ear position over plant height (REPH), variance analysis indicated plant height among replications was significantly different, while ear height and REPH showed no significant difference among replication (Table 1). The trial results are in agreement with those of Viana and Matta (2003). Especially, the difference in plant height among replications may be considered due to Hawaii's trade wind while ear height seemed less influenced by the trade wind. Differences in plant height, ear height and REPH for five parents and ten $\mathrm{F}_{1}$ hybrids were highly significant $(p<0.01)$ except REPH for ten hybrids with significance at $5 \%$ level of probability.

Plant height for five parents and ten hybrids (Table 2) ranged from $142.2 \mathrm{~cm}(\mathrm{Pi} 31)$ to $177.53 \mathrm{~cm}(\mathrm{Hi} 26)$ and from $189.87 \mathrm{~cm}$ (Pi23× Pi31) to $229.8 \mathrm{~cm}$ (Hi26× Pi17). The highest inbred line Hi26 produced highest hybrids in average while the lowest inbred line Pi31 made lowest hybrids. In general, the hybrids made by the inbred lines Pi23, Pi31 produced lower plant height. Average heterosis effect for plant height was $33.3 \%$ and the hybrid by the inbred line Pi31 showed highest and

\begin{tabular}{|c|c|c|c|c|}
\hline \multirow{2}{*}{ Source } & \multirow{2}{*}{ Df } & \multicolumn{3}{|c|}{ Mean squares } \\
\hline & & Plant height & Ear height & $\mathrm{REPH}^{\mathrm{a}}$ \\
\hline Total & 224 & & & \\
\hline Reps & 2 & $2,757.35 * *$ & 498.57 ns & 46.31 ns \\
\hline Entries & 14 & $12,303.56 * *$ & $7,434.48 * *$ & $461.12 * *$ \\
\hline Parents & 4 & $2,971.91 * *$ & $1,319.53 * *$ & $319.75 * *$ \\
\hline P vs $\mathrm{H}$ & 1 & $136,904.00 * *$ & $94,873.68 * *$ & $4,596.89 * *$ \\
\hline Hybrids & 9 & $2,606.47 * *$ & $436.77 * *$ & $64.42 *$ \\
\hline Exp. Error & 28 & 367.47 & 195.13 & 24.54 \\
\hline Sample Error & 180 & 33.32 & 29.38 & 11.2 \\
\hline
\end{tabular}

Table 1. Analysis of variance for plant height, ear height and REPH of five parents and their ten diallel crosses

*, **; $5 \%$ and $1 \%$ levels of significant, ${ }^{\text {Ns}}$; not significant. ${ }^{a} \mathrm{REPH}$; Relative ear position over plant height.

\begin{tabular}{|c|c|c|c|c|c|c|}
\hline \multicolumn{7}{|c|}{ Parent } \\
\hline Parent & Hi26 & Hi34 & Pi17 & Pi23 & Pi31 & Array mean \\
\hline \multirow[t]{3}{*}{$\mathrm{Hi} 26$} & $177.53^{\mathrm{a}}$ & 223.60 & 229.80 & 213.13 & 223.40 & $222.48^{*}$ \\
\hline & & $38.11^{\mathrm{b}}$ & 34.99 & 27.21 & 39.77 & $35.00 * *$ \\
\hline & & $20.81^{c}$ & 22.99 & 11.15 & 26.79 & $13.09 * * *$ \\
\hline \multirow[t]{3}{*}{ Hi34 } & & 146.27 & 210.47 & 207.60 & 201.47 & 210.78 \\
\hline & & & 36.21 & 36.66 & 39.47 & 37.16 \\
\hline & & & 19.28 & 21.23 & 20.48 & -2.53 \\
\hline \multirow[t]{3}{*}{ Pi17 } & & & 163.07 & 204.13 & 193.27 & 209.42 \\
\hline & & & & 27.33 & 26.46 & 31.22 \\
\hline & & & & 13.75 & 8.26 & 1.49 \\
\hline \multirow[t]{3}{*}{ Pi23 } & & & & 157.67 & 189.87 & 203.68 \\
\hline & & & & & 26.16 & 29.44 \\
\hline & & & & & 9.68 & -3.33 \\
\hline \multirow[t]{2}{*}{ Pi31 } & & & & & 142.20 & 202.00 \\
\hline & & & & & & $\begin{array}{l}33.22 \\
-8.71\end{array}$ \\
\hline
\end{tabular}

Table 2. Average values (cm), heterosis effect (\%), and SCA and GCA effects for plant height of five parents and their ten diallel crosses

$*$ Grand mean $=192.23 \mathrm{~cm}$, parental mean $=157.35 \mathrm{~cm}, \mathrm{~F}_{1}$ mean $=209.67 . * *$ Grand mean $=33.3 \%$. ** GCA effect, $\mathrm{SE}$ of $\mathrm{SCA}=3.74, \mathrm{SE}$ of $\mathrm{GCA}=7.64$. ${ }^{\mathrm{a}}$ Average plant height $(\mathrm{cm})$. ${ }^{\mathrm{b}}$ Heterosis effect $(\%)$. ${ }^{\mathrm{c}} \mathrm{SCA}$ effect $\left(\mathrm{s}_{\mathrm{jj}}\right)$. 
lowest heterosis. Zanoni and Dudely (1980) observed quite similar mid-parent heterosis (39.4\%) from inbred crosses. All crosses showed positive heterosis effects. Heterosis effects was ranged from $39.7 \%$ for the cross Hi26× Pi31 and the cross Hi34× Pi31 to $26.6 \%$ for the cross Pi23× Pi31.

Mean squares for GCA and SCA effects for plant height were significant at 5\% and 1\% levels, respectively (Table 5). The SCA effect was greater than GCA effect, indicating greater importance of dominance gene effects for plant height. Among five parent lines, the highest inbred line Hi26 had highest GCA effect and the inbred line Pi31 showed lowest GCA effect (Table 2). The SCA effects of the ten hybrids ranged from 8.26 for the cross Pi17× Pi31 to 26.79 for the cross Hi26× Pi31. Hybrids by three Philippine inbred lines exhibited lowest SCA effects as expected. In general, the hybrid with inbred line Hi26 showed highest SCA effects except for the cross Hi26× Pi23 (11.15) that gave low SCA effect that was even less than GCA effect.

Average values of ear height for two parents, Hi26 and Pi36 were $59.40 \mathrm{~cm}, 80.80 \mathrm{~cm}$, respectively (Table 3). Among hybrids, the cross Hi26× Hi34 was highest while the cross Pi23× Pi31 showed lowest plant height. Ear height seemed to follow same pattern with plant height. Average heterosis effect for ear height was $61.9 \%$, which was about twice as much that of plant height. Average heterosis effect for five inbreds ranged from 58.2\% for Hi26 to $67.3 \%$ for the inbred line Pi31. The lowest inbred line Pi31 had the highest heterosis and vice versa. The cross Hi26× Pi23 showed the lowest heterosis of $42.3 \%$.

Unlike plant height, only mean square for SCA effect of ear height was highly significant (Table 5). The SCA effect was about six times greater than that of GCA effect and the ratio of GCA to SCA was 0.15. The GCA effects of ear height for five inbreds ranged from -5.28 for Pi31 to 4.59 for Hi26 (Table 3). The cross Pi23x Pi31 had the lowest SCA for not only plant height but also ear height. However, the SCA effects for the cross Pi17× Pi23 and the cross Pi17× Pi31 were similar to SCA effect of the cross Hi26× Hi34. Inbred lines Pi23 and Pi31 might be the closest among the Philippine inbred lines. Overall average of relative ear position was $51.7 \%$ with inbred lines being $45.3 \%$ and hybrids being $54.9 \%$ (Table 4). When crossed, ear position came up over 50\%. Among inbred lines, the parent Pi17 had lowest REPH. It has its uppermost ear at $39.77 \%$ in plants. The Philippine inbred line Pi31 had its ear in middle line in plants ranked highest in REPH. REPH becomes valuable when compared to ear height. Although the inbred line Pi31 had lowest ear height, it had higher ear position in plant. Thus, it is very important to consider REPH as one of selection criterion for low ear position. Array mean for inbred lines was quite similar from $53.11 \%$ for the inbred line Hi26 to 55.99\% for the inbred line Hi34 when considering differences among inbreds per se. Two lowest inbred lines, Pi17 and Pi31 produced a second highest hybrid in REPH. However, lower inbred lines usually produced ears at relatively lower position.

An average heterosis effect for REPH was 21.6\%, which is less than those of plant and ear height (Table 4). Average heterosis effect for five inbred lines ranged from $16.33 \%$ for the inbred line Pi 23 to $26.37 \%$ for the inbred line Pi31. The cross Pi23× Pi31 had the highest heterosis effect of $39.99 \%$. Mean square for SCA effect of REPH was highly significant but not in GCA effect. The ratio of GCA to SCA for REPH was 0.42 (Table 5). The GCA effects for five parents ranged from -0.97 to 1.64 (Table 4). The three inbred lines Hi26, Pi17 and Pi31 had negative GCA effects but inbred lines Hi34 and Pi23 showed positive values. The cross Hi34× Pi23 had the lowest SCA effect while the cross Pi17× Pi31 was

Table 3. Average values (cm), heterosis effect (\%), and SCA and GCA effects for ear height of five parents and their ten diallel crosses

\begin{tabular}{|c|c|c|c|c|c|c|}
\hline \multicolumn{7}{|c|}{ Parent } \\
\hline Parent & $\mathrm{Hi} 26$ & $\mathrm{Hi} 34$ & Pi17 & $\mathrm{Pi} 23$ & Pi31 & Array mean \\
\hline \multirow[t]{3}{*}{ Hi26 } & $80.80^{\mathrm{a}}$ & 122.13 & 119.33 & 114.47 & 116.07 & $118.00 *$ \\
\hline & & $60.99^{b}$ & 64.00 & 42.33 & 65.64 & $58.20 * *$ \\
\hline & & $15.67^{\mathrm{c}}$ & 16.32 & 8.75 & 16.51 & $4.59 * * *$ \\
\hline \multirow[t]{3}{*}{ Hi34 } & & 71.00 & 115.53 & 115.73 & 117.47 & 117.72 \\
\hline & & & 70.21 & 53.20 & 80.22 & 66.11 \\
\hline & & & 15.49 & 12.98 & 20.88 & 1.63 \\
\hline \multirow[t]{3}{*}{ Pi17 } & & & 64.73 & 114.73 & 109.60 & 114.80 \\
\hline & & & & 58.50 & 76.66 & 67.30 \\
\hline & & & & 15.44 & 16.47 & -1.82 \\
\hline \multirow[t]{3}{*}{$\mathrm{Pi} 23$} & & & & 80.07 & 102.53 & 111.87 \\
\hline & & & & & 47.00 & 50.33 \\
\hline & & & & & 6.70 & 0.88 \\
\hline \multirow[t]{3}{*}{ Pi31 } & & & & & 59.40 & 111.42 \\
\hline & & & & & & 67.13 \\
\hline & & & & & & -5.28 \\
\hline
\end{tabular}

$*$ Grand mean $=100.24 \mathrm{~cm}$, parental mean $=71.20 \mathrm{~cm}, \mathrm{~F}_{1}=114.76 \mathrm{~cm} . * *$ Grand mean $=61.9 \%$. *** GCA effect, SE of SCA $=5.57, \mathrm{SE}$ of $\mathrm{GCA}=2.73$. ${ }^{\mathrm{a}}$ Average ear height $(\mathrm{cm})$. ${ }^{\mathrm{b}}$ Heterosis effect $(\%),{ }^{\mathrm{c}} \mathrm{SCA}$ effect $\left(\mathrm{s}_{\mathrm{jij}}\right)$. 
Table 4. Average percentage (\%), heterosis effect (\%), and SCA and GCA effects for REPH of five parents and their ten diallel crosses

\begin{tabular}{|c|c|c|c|c|c|c|}
\hline \multicolumn{7}{|c|}{ Parent } \\
\hline Parent & Hi26 & Hi34 & Pi17 & Pi23 & Pi31 & Array mean \\
\hline \multirow[t]{3}{*}{ Hi26 } & $45.55^{\mathrm{a}}$ & 54.60 & 51.99 & 53.81 & 52.01 & $53.11 *$ \\
\hline & & $16.10^{\mathrm{b}}$ & 21.71 & 11.77 & 19.22 & $17.22 * *$ \\
\hline & & $2.38^{c}$ & 2.65 & 1.43 & 2.02 & $-0.97 * * *$ \\
\hline \multirow[t]{3}{*}{$\mathrm{Hi} 34$} & & 48.66 & 54.89 & 55.88 & 58.45 & 55.99 \\
\hline & & & 24.33 & 12.22 & 29.21 & 20.42 \\
\hline & & & 3.19 & 0.89 & 5.87 & 1.56 \\
\hline \multirow[t]{3}{*}{ Pi17 } & & & 39.77 & 56.13 & 57.00 & 55.00 \\
\hline & & & & 24.31 & 39.99 & 27.56 \\
\hline & & & & 4.46 & 7.55 & -1.50 \\
\hline \multirow[t]{3}{*}{ Pi23 } & & & & 50.81 & 54.11 & 55.00 \\
\hline & & & & & 17.00 & 16.33 \\
\hline & & & & & 1.53 & 1.64 \\
\hline \multirow[t]{3}{*}{ Pi31 } & & & & & 41.72 & 55.45 \\
\hline & & & & & & 26.37 \\
\hline & & & & & & -0.74 \\
\hline
\end{tabular}

$*$ Grand mean $=51.7 \%$, Parental mean $=45.3 \%, \mathrm{~F}_{1}$ mean $=54.9 \% . * *$ Grand mean $=21.6 \% . * * * \mathrm{GCA}$ effect, $\mathrm{SE}$ of SCA $=1.97, \mathrm{SE}$ of GCA $=$

0.97. ${ }^{\mathrm{a}}$ Average REPH (\%). ${ }^{\mathrm{b}}$ Heterosis effect (\%), ${ }^{\mathrm{C}} \mathrm{SCA}$ effect $\left(\mathrm{s}_{\mathrm{j}}\right)$.

Table 5. Mean squares for GCA and SCA and ratios of GCA to SCA (GCA/SCA) for plant height, ear height and REPH

\begin{tabular}{lccc}
\hline & Plant height & Ear height & $\mathrm{REPH}^{\mathrm{c}}$ \\
\hline $\mathrm{GCA}^{\mathrm{a}}$ & $467.09^{*}$ & $97.61 \mathrm{~ns}$ & $15.54 \mathrm{~ns}$ \\
$\mathrm{SCA}^{\mathrm{b}}$ & $961.49^{* *}$ & $654.84^{* *}$ & $36.82^{* *}$ \\
Ratio & 0.49 & 0.15 & 0.42
\end{tabular}

$*, * * ; 5 \%$ and $1 \%$ levels of significant

${ }^{\mathrm{a}}$ GCA: General Combining Ability. ${ }^{\mathrm{b}} \mathrm{SCA}$ : Specific Combining

Ability. ${ }^{c} \mathrm{REPH}$ : Relative ear position over plant height.

the highest.

There were significant differences for plant height, ear height and REPH between the parents and the hybrids. We observed great heterosis in all three traits studied. Heterosis in those traits is probably one of greatest among important agronomic traits in maize because heterosis for those traits is great. It is possible to reduce them quickly by inbreeding. Since lower REPH hybrids were generated by lower REPH parents. Inbred development for low ear position may be better achieved by starting with low REPH hybrids or population. It is worth calculating REPH based on plant and ear height in inbred lines development for new hybrids since REPH provides valuable insight in selection for low ear position. REPH also could be used as one of valuable selection criteria over plant and ear heights in the breeding program for low ear height. Care must be taken to select inbreds by plant types like those characters since even inbred lines with low ear position produced a higher ear position hybrid.

As new varieties are developed, plant and ear height are considered not only morphological traits, but also other traits, since it is closely connected with such as flowering date and yield. Especially, research on plant and ear height need to more continue in the future, and statistical access method should be considered due to two statistical methods produced some different results.

\section{REFERENCES}

Allen, J. R., G. W. Mckee and J. H. McGahen 1973 Leaf number and maturity in hybrid corn. Agron. J., 65: 233-235

Baktash, F. Y. and A. D. Mazaal 1985 Effect of seeding dates and genotypes on corn grain yield. J. Agr. Water Resources Res., 4: $1-11$

Baynes, R. A. and R. I. Brawn 1973 Influence of cytoplasmic effects on some agronomic characters in corn. Can. J. Plant Sci., 53: 101-104

Beavis, W. D. Grant, D. Albertsen and M. Fincher 1991 Quantitative trait loci for plant height in four maize populations and their associations with qualitative genetic loci. Theor. Appl. Genet., 83: 141-145

Begna, S. H., R. I. Hamilton, L. M. Dwyer, D. W. Stewart and D. L. Smith 2000 Variability among maize hybrids differing in canopy architecture for above-ground dry matter and grain yield. Maydica, 45: 135-141

Bodzon Z. 2004 Correlation and heritability of the characters determining the seed yield of the long-raceme alfalfa (Medicago sativa L.). J. App. Genet., 45: 49-59

Bourland, F. M. and N. P. Tugwell 1999 Evaluation of injury by tarnished plant bugs to blended cotton genotypes. J. Cotton Sci., 3: 171-176

Burow, M. D. and J. G. Coors 1994 DIALLEL: A micro computer program for the simulation and analysis of diallel crosses. Agron. J., 86: 154-158

Crossa, J. S. and E. J. Wellhausen 1990 Heterotic patterns among mexican races of maize. Crop Sci, 30: 1182-1190

Cruz, C. D. and R. Vencovsky 1989 Comparação de alguns métodos de análise dialélica. Rev. Bras. Genet., 12: 425-438

Doerksen, T. K., L. W. Kannenberg and E. A. Lee 2003 Effect of recurrent selection on combining ability in maize breeding populations. Crop Sci., 43: 1652-1658

Dorrance, A. E., K. H. Hinkelmann and H. L. Warren 1998 Diallel analysis of diplodia ear rot resistance in Maize. Plant Disease, 82: 699-703

Edward, M. D., C. W. Stuber and J. F. Wendell 1987 Molecular marker-facilitated investigations of QTL in maize. I. Numbers, 
genomic distribution, and types of gene action. Genetics, 116: $113-125$

Gardner, C. O. and S. A. Eberhart 1966 Analysis and interpretation of the variety cross diallel and related populations. Biometrics, 22: 439-452

Gerrish, E. E. 1983 Indications from a diallel study for interracial maize hybridization in the corn belt. Crop Sci, 23: 1082-1084

Griffing, B. 1956 Concept of general and specific combining ability in relation to diallel crossing systems. Aust. J. Bio. Sci., 9: 463-493

Guo, P. Z., C. O. Gardner and M. Obaidi 1986 Genetic variation and gene effects controlling prolificacy and other traits in maize (Zea mays L.). Acta Gen. Sinica, 13: 35-42

Hakizimana, F., M. Ibrahim, A. C. Langham, S. D. Haley and J. C. Rudd 2004 Diallel analysis of wheat streak mosaic virus resistance in winter wheat. Crop Sci, 44: 89-92

Harville, B. G. 1977 Inheritance of ear height and associated characters of corn (Zea mays L.) Dissertation Abstract Int., 37: 3699-3700B

Huber, D. A., T. L. White, R. C. Littlell and G. R. Hodge 1992 Ordinary least squares estimation of general and specific combining abilities from half-diallel mating designs. Silvae Genetica, 41: 263-273

Hui, D. F., C. J. Jiang and H. D. Mo 1997 Comparison among mapping methods for detecting QTLs and estimating their effects. Acta Agr. Sinica, 23: 129-136

Jinks, J. L. and B. I. Hayman 1953 The analysis of diallel crosses. Maize Gen. Coop. Newsletter, 27: 48-54

Lee, M. and L. R. Veldboom 1993 Quantitative genetic variation near an1 and bx1. Maize Gen. Coop. Newsletter, 67: 6

Legg, J. G. and A. A. Fleming 1973 Inheritance of a new brachyism in corn, Zea mays L. Crop Sci., 13: 322-324

Manson, L., C. L. Mondart, C. R. Chaney, P. Martin and M. Milam 1974 Corn forage as affects by plant population, nitrogen rate and hybrid on Oliver soil. Bull. Agr. Exp. Stat. Louisianns St. Unis., 677: 23

Magari, R. and M. S. Kang 1994 Interactive BASIC program for Griffing's diallel analyses. J. Hered., 85: 336

Mckee, G. W., J. H. Mcgrahen, R. A. Peiffer and J. R. Allen 1974 Interrelationships of maturity, leaf area index, time of black layer formation, heat units and yield of 120 corn hybrids. Agron. Abstr., 87

Mock, J. J. and A. A. Bakri 1976 Recurrent selection for cold tolerance in maize. Crop Sci., 16: 230-233

Mungoma, C. and L. M. Pollak 1988 Heterotic patterns among 10 corn belt and exotic maize populations. Crop Sci., 28: 500-504

Nigussie, M. and H. Zelleke 2001 Heterosis and combining ablility in a diallel among eight elite maize populations. African Crop Sci. J., 9: 471-479

Nyhus, K. A., W. A. Russel and W. D. Guthrie 1989 Change in agronomic traits associated with recurrent selection in two maize synthetics. Crop Sci., 29: 269-275

Obilana, A. T. and A. R. Hallauer 1974 Estimation of variability of quantitative traits in BSSS by using unselected maize inbred lines. Crop Sci., 14: 99-103

Park, K. Y., Y. K. Kang, S. U. Park and H. G. Moon 1989 Effects of planting density and tiller removal on growth and yield of sweet corn hybrids. Korean J. Crop Sci., 34: 192-197

Pratta, G., Z. Roxana and A. L. Picardi 2003 Diallel analysis of production traits among domestic, exotic and mutant germplasms of Lycopersicon. Genet. Mol. Res., 2: 206-213

Quendaba, B., W. W. Hanna, G. Ejeta, W. E. Nyquist and J. B. Santini 1996 Forage yield and digestibility of African pearl millet landraces in diallel with missing cross. Crop Sci., 36: $1517-1520$

Russel, W. A. 1976 Genetic effects and genetic effect X year interactions at three gene loci in sublines of a maize inbred line. Can. J. Gen. Cyto., 18: 23-33

Sheridan, W. F. 1988 Maize developmental genetics: genes of morphogenesis. Annu. Rev. Genet, 22: 353-385

Soriano, V. J. M. 2000 The parametric restrictiond of the griffing diallel analysis model: combining ability analysis. Gen. Mol. Biol., 23: 877-881

Subhan, M., M. Qasim, Riaz ud Din Ahmad, M. U. Khan, M. A. Khan and M. A. Amin 2003 Combining ability for yield and its components in Up-land Cotton. Asian J. Plant Sci., 2: $519-522$

Surányi, J. and G. Y. Mándy 1955 A kukorica. (Corn) Magyarország kultúrflórája. (Culture flora of Hungary) Akadémiai Kiadó, Budapest.

Thompson, S. A. 1983 Mass selection for prolificacy in corn at high and low plant densities: Cycle means and geneotypic variations. Dissertation Abstracts. International, 43: 2414B

Troyer, A. F. and J. R. Larkins 1985 Selection for early flowering in corn: 10 late synthetics. Crop Sci., 25: 695-697

Veldboom, L. R., M. Lee and W. L. Woodman 1994 Molecular marker-facilitated studies in an elite maize population: I. Linkage analysis and determination of QTL for morphological traits. Theor. Appl. Genet., 88: 7-16

Vencovsky, R. 1970 Alguns aspectos teóricos e aplicodos relatives a cruzamentos dialelicos de variedades. Tese de Livre-Docencia, ESALQ-USP, Piracicaba, Brazil

Viana, J. M. S. and F. D. P. Matta 2003 Analysis of general and specific combining abilities of popcorn populations, including selfed parents. Gen. Mol. Biol., 26: 465-471

Widstrom, N. W. and M. E. Snook 1998 Genetic variation for maysin and its analogues in crosses among corn inbreds. Crop Sci., 38: 372-375

Yap, T. C. and S. T. Tan 1974 Evaluation of recurrent selection based on rouging, $\mathrm{S} 1$ progeny test and $\mathrm{S} 1$ line breeding in a sweet corn variety. Malysian Agri. Res., 3: 222-226

Zanoni, U. and J. W. Dudley 1980 Comparison of different methods of identifying inbreds useful for improving elite maize hybrids. Crop Sci., 29: 577-582

Zhang, Y.,. M. S. Kang and R. L. Kendall 2005 A comprehensive program for Griffing's and Gardner-Eberhart analyses. Agron. J., 97: 1097-1106 